Volume 20 Number 1 June 2020. P.24-37

https://doi.org/10.30603/au.v20i1.1171

\title{
The Alternative Strategies for Accelerating Islamic Banking Growth: Mergers, Spin-Offs, Acquisitions and Conversions.
}

\author{
M. Nur Rianto Al Arif ${ }^{1}$, Aini Masruroh ${ }^{2}$, Dwi Nuraini Ihsan ${ }^{3}$, Yuke Rahmawati ${ }^{4}$ \\ 1,2,3,4Universitas Islam Negeri (UIN) Syarif Hidayatullah Jakarta
}

\begin{abstract}
The year 2023 is the deadline for sharia business units to decide on the business strategy to be carried out. This study aims to determine alternative strategies that can be carried out by sharia business units in accelerating business growth. The approach taken in this paper is a mixture of qualitative and quantitative approaches. A qualitative approach using SWOT analysis and interviews. While the quantitative approach using ARIMA. The ARIMA results show that no sharia business unit can achieve a 50\% share of assets from its parent bank. This shows the spin-off strategy as mandated by the law needs to be evaluated. Alternative strategies that can be done is conversion, where there are already two banks that do this strategy. Also, another alternative strategy that can be taken is a merger between Islamic business units. Another alternative strategy is the acquisition of sharia business units by established sharia full-fledged banks.
\end{abstract}

\section{Strategi Alternatif Untuk Akselerasi Pertumbuhan Bank Syariah: Penggabungan, Pemisahan, Akuisisi, dan Konversi}

\begin{abstract}
Abstrak
Tahun 2023 merupakan batas akhir bagi unit usaha syariah untuk memutuskan strategi bisnis yang akan dilakukan. Penelitian ini bertujuan untuk mengetahui alternatif strategi yang dapat dilakukan oleh unit usaha syariah dalam mengakselerasi pertumbuhan bisnisnya. Pendekatan yang diambil dalam paper ini ialah pendekatan campuran antara kualitatif dengan kuantitatif. Pendekatan kualitatif dengan menggunakan analisis SWOT dan wawancara. Sedangkan pendekatan kuantitatif dengan menggunakan ARIMA. Hasil ARIMA menunjukkan bahwa tidak ada satupun unit usaha syariah yang mampu mencapai $50 \%$ share aset dari bank induknya. Hal ini menunjukkan strategi spin-off sebagaimana yang diamanatkan oleh undang-undang perlu dievaluasi. Alternatif strategi yang dapat dilakukan ialah konversi, dimana sudah terdapat dua bank yang melakukan strategi ini. Selain itu, alternatif strategi lain yang dapat ditempuh ialah merger antar unit usaha syariah. Alternatif strategi lainnya ialah akuisisi unit usaha syariah oleh bank umum syariah yang sudah berdiri.
\end{abstract}

Kata Kunci: Islamic business unit, spin-off, merger, conversion, acquisition

Author correspondence

Email: mnur.rianto@uinjkt.ac.id,2aini.m@uinjkt.ac.id,32dwinuraini@uinjkt.ac.id,

4yuke.rahmawati@uinjkt.ac.id

_Available online at http://journal.iaingorontalo.ac.id/index.php/au/index 


\section{A. Introduction}

The development of sharia banking in Indonesia is quite rapid, this can be seen until the end of 2019 there have been 14 sharia commercial banks, 20 sharia business units, and 164 BPRS. The addition of the number of Islamic commercial banks occurred mainly after the issuance of Law no. 21 of 2008 concerning Islamic Banking. This fairly rapid development apparently was still unable to reach the target market share of sharia banking to national banks by $5 \%$ in 2008 . This target based on the sharia banking blueprint should have been achieved in 2008. The target of achieving a market share of 5\% was only achieved in end of 2016 (for details is shown in Table 1).

Table 1. The Market Share Growt of Indonesian Islamic Banking Industry

\begin{tabular}{cccc}
\hline Year & $\begin{array}{c}\text { Islamic Banking } \\
\text { (million rupiah) }\end{array}$ & $\begin{array}{c}\text { Conventional banking } \\
\text { (million rupiah) }\end{array}$ & $\begin{array}{c}\text { Market share } \\
\text { (\%) }\end{array}$ \\
\hline 2008 & $49,555,122$ & $2,261,001,878$ & 2.14 \\
2009 & $66,090,000$ & $2,486,016,000$ & 2.61 \\
2010 & $97,519,000$ & $2,911,334,000$ & 3.24 \\
2011 & $145,467,000$ & $3,507,365,000$ & 3.98 \\
2012 & $195,018,000$ & $4,067,569,000$ & 4.58 \\
2013 & $242,276,000$ & $4,712,191,000$ & 4.89 \\
2014 & $244,197,000$ & $4,763,898,000$ & 4.88 \\
2015 & $296,262,000$ & $6,132,583,000$ & 4.83 \\
2016 & $356,504,000$ & $6,729,799,000$ & 5.29 \\
2017 & $424,181,000$ & $7,387,634,000$ & 5.74 \\
2018 & $477,327,000$ & $8,068,346,000$ & 5.92 \\
\hline
\end{tabular}

Source: Islamic Banking Statistics

In the context of accelerating the growth of Islamic banking, the regulator encouraged the birth of a law specifically regulating the Islamic banking industry, in 2008 a law was issued specifically regulating Islamic banking, namely Law (Law) No. 21 of 2008. One of the crucial things in this law that is able to accelerate the development of sharia banking in Indonesia is related to the spin-off of Islamic business units both voluntary and mandatory if Islamic business unit assets have reached $50 \%$ of the assets of the parent bank or 15 years after Law No. 21 of 2008 enacted. 
The alternative strategies for accelerating islamic banking growth: mergers, spinoffs, acquisitions and conversions.

After the enactment of this Law, the regulator encouraged several sharia business units to make a spin-off even though they did not meet the criteria as stated in the law. The spin-off policy that is implemented raises new problems in the level of efficiency in the Islamic banking industry, where the spin-off policy actually causes a decrease in the level of efficiency of the Islamic banking industry ${ }^{1}$. The Islamic banks becames less efficient that before do the spin-off ${ }^{2}$. Besides that, there is no Islamic business units can fulfill the requirement of 50\% market share from its parents banks ${ }^{3}$. Therefore, the spin-off policy must still be evaluated in its application ${ }^{4}$, especially for the Islamic business units from regional development banks ${ }^{5}$. The small asset size of spin-off banks will become an obstacle for further growth.

This shows that the spin-off that was originally intended to accelerate the growth of Islamic banks actually shows the opposite in recent years. Resulting in new problems if the Islamic business unit is separated. The researcher formulates the core problem with the best alternative strategy which can be taken by the Islamic business unit to accelerate the growth of the sharia banking industry.

There are alternative strategies that can be taken besides the spin-off policy, namely mergers. In this policy several Islamic business units can be merged to form a separate Islamic commercial bank. Merger will be able to strengthen the capital aspects of Islamic banks ${ }^{6}$, and can compete in the ASEAN Economi Community ${ }^{7}$ (Ahdizia et al, 2018). In addition, another strategy that can be done is

${ }^{1}$ M. Nur Rianto Al Arif. (2015). Keterkaitan Kebijakan Pemisahan Terhadap Tingkat Efisiensi Pada Industri Perbankan Syariah di Indonesia. Jurnal Keuangan dan Perbankan, Vol. 19 (2), 295.

${ }^{2}$ Pambuko, Z. B. (2019). Kebijakan Spin-off dan Efisiensi Perbankan Syariah di Indonesia. Ihtifaz: Journal of Islamic Economics, Finance, and Banking, Vol. 2(1), 21

${ }^{3}$ M Nur Rianto Al Arif, Nachrowi Djalal Nahcrowi, Mustafa Edwin Nasution, \& T. M. Zakir Mahmud. (2018). Evaluation of The Spin-offs Criteria: A Lesson from the Indonesian Islamic Banking Industry. Iqtishadia, Vol. 11 (1), 85

${ }^{4}$ M Nur Rianto Al Arif, Nachrowi Djalal Nahcrowi, Mustafa Edwin Nasution, \& T. M. Zakir Mahmud. (2017). The Islamic Banking Spin-Off: Lessons from Indonesian Islamic Banking Experiences. Journal of King Abdul Aziz University: Journal of Islamic Economics, Vol. 30 (2), 117

5 Ismawati Haribowo. (2017). The Indonesian Islamic Bank's Spin-off: a Study in Regional Development Banks. Al-Iqtishad: Jurnal Ilmu Ekonomi Syariah (Journal of Islamic Economics), Vol. $9(1), 53$

${ }^{6}$ Kindy Miftah, \& Hendro Wibowo. (2017). Merger and Industrial Acceleration: Study at Indonesian Islamic Banking Industry. Signifikan: Jurnal Ilmu Ekonomi, Vol. 6(1), 29

${ }^{7}$ Khulifa Ahdizia, Dian Masyita, \& Sutisna. (2018). Business Valuation of Islamic Banks in the Merger Plan to Become Indonesia's State-Owned Bank. Etikonomi, Vol. 17(2), 223 
the conversion of conventional banks into Islamic commercial banks. Full conversion has been carried out by Bank Aceh and Bank NTB. Conversion to Islamic commercial banks can be an alternative strategy to accelerate the Islamic banking industry. Another strategy that might be taken is the acquisition of sharia business units by Islamic commercial banks that have entered into BUKU 2 or BUKU 3.

Although there have been several studies that discuss various strategies, but previous studies are still doing partially. This research tries to fill the gap by conducting a comprehensive study of these various strategies. So, this research contributes to a comprehensive study of various strategies that can be carried out to accelerate the growth of Islamic banks. Therefore, this research aims to conduct a comprehensive study of various alternative strategies that can be carried out by Islamic banks.

\section{B. Forecasting of Islamic Business Unit Readiness}

Forecasting results in Table 2 indicate that the overall sample banks are unable to reach $50 \%$ of the parent bank's market share. The largest market share expectations that were able to be achieved were UUS Maybank Indonesia (18.05\%), UUS Bank Sinarmas (16.53\%), and UUS Bank Permata (16.22\%). This shows that in fact that there will be no sharia business unit that is able to meet the specified spin-off criteria as stated in the Act.

Table 2. The Forecasting Resul

\begin{tabular}{clcc}
\hline No & \multicolumn{1}{c}{ Banks } & Current Year & Predicted Value (2023) \\
\hline 1 & UUS Bank of Sumatera & $9.51 \%$ & $11.86 \%$ \\
& Utara & $6.45 \%$ & $15.01 \%$ \\
2 & $\begin{array}{l}\text { UUS Bank of Sumatera } \\
\text { Barat }\end{array}$ & $11.30 \%$ & $14.33 \%$ \\
3 & UUS Bank of Sumsel \& & $9.31 \%$ & $11.55 \%$ \\
& Babel & $6.91 \%$ & $8.76 \%$ \\
4 & UUS Bank of Riau \& Kepri & $8.18 \%$ & $11.79 \%$ \\
5 & UUS Bank of Yogyakarta & $4.86 \%$ & $14.12 \%$ \\
6 & UUS Bank of DKI & $6.74 \%$ & $10.50 \%$ \\
7 & UUS Bank of Jawa Timur & &
\end{tabular}


The alternative strategies for accelerating islamic banking growth: mergers, spinoffs, acquisitions and conversions.

\begin{tabular}{clcc}
9 & UUS Bank of KalBar & $9.61 \%$ & $13.54 \%$ \\
10 & UUS Bank of KalSel & $10.21 \%$ & $12.53 \%$ \\
11 & UUS Bank of KalTim & $10.53 \%$ & $12.65 \%$ \\
12 & UUS Bank of Sulselbar & $5.13 \%$ & $6.18 \%$ \\
13 & UUS Bank of Jambi & $12.35 \%$ & $14.85 \%$ \\
14 & UUS Bank of BTN & $8.95 \%$ & $12.43 \%$ \\
15 & UUS Bank of Permata & $14.22 \%$ & $16.22 \%$ \\
16 & UUS Bank of CIMB Niaga & $8.88 \%$ & $10.27 \%$ \\
17 & UUS Bank of OCBC NISP & $1.98 \%$ & $2.85 \%$ \\
18 & UUS Bank of Danamon & $2.79 \%$ & $4.29 \%$ \\
19 & UUS Maybank Indonesia & $16.96 \%$ & $18.05 \%$ \\
20 & UUS Bank of Sinarmas & $14.32 \%$ & $16.53 \%$ \\
\hline
\end{tabular}

Source: Processing Data.

Next, we will do a simple simulation using compound growth. Based on the results in Table 3 shows that if the Islamic business unit wants to reach $50 \%$ of the proportion of the assets of the parent bank, then they must have an average growth rate of assets per year above 30\% (assuming the parent bank only grows $5 \%$ per year). even the sharia business unit of Bank OCBC must have an asset growth of $83 \%$ per year. In addition, it must have an average asset growth rate of $40 \%$ per year (assuming the parent bank's asset growth is $10 \%$ per year). The smallest average growth that must be carried out by sharia business units (assuming growth of the parent bank is 5\% per year) is sharia business units of Bank Sinarmas (27\% / year), sharia business units of Bank Kalbar (29\% / year), and sharia business unit of the Sumsel Babel Bank (32.6\%). While the largest average growth that must be carried out by UUS (assuming growth of the parent bank is $5 \%$ per year) is the sharia business unit of Bank OCBC (83\% / year), sharia business unit of Bank Danamon (68\% / year), and the unit Islamic business from Bank Jatim (55.5\% / year). However, this growth target will be very difficult to achieve because both the Islamic business unit and its parent bank are growing each year. In addition, the growth of assets that is too high can have a long-term impact that is not good for the performance of the relevant Islamic business units. If the bank pursues high asset growth, the bank will mean sacrificing the prudential aspects of its operational management. 
Tabel 3. Growth Simulation of Islamic Business Units

\begin{tabular}{|c|c|c|c|c|}
\hline No & Bank & $\begin{array}{l}\text { Pertumbuhan } \\
\text { Aset UUS }\end{array}$ & $\begin{array}{c}\text { Pertumbuhan } \\
\text { Aset Bank Induk }\end{array}$ & $\begin{array}{c}\text { Proporsi } \\
\text { Aset }\end{array}$ \\
\hline \multirow{2}{*}{1} & \multirow{2}{*}{ UUS Bank of SuMut } & $43.5 \%$ & $5.0 \%$ & $50.45 \%$ \\
\hline & & $51.5 \%$ & $10.0 \%$ & $51.5 \%$ \\
\hline \multirow{2}{*}{2} & \multirow{2}{*}{ UUS Bank of SumBar } & $47.5 \%$ & $5.0 \%$ & $50.98 \%$ \\
\hline & & $55.5 \%$ & $10.0 \%$ & $50.42 \%$ \\
\hline \multirow{2}{*}{3} & UUS Bank of SumSel \& & $32.6 \%$ & $5.0 \%$ & $50.05 \%$ \\
\hline & Babel & $40.2 \%$ & $10.0 \%$ & $50.38 \%$ \\
\hline \multirow{2}{*}{4} & \multirow{2}{*}{ UUS Bank of Riau Kepri } & $40 \%$ & $5.0 \%$ & $50.19 \%$ \\
\hline & & $47.8 \%$ & $10.0 \%$ & $50.06 \%$ \\
\hline \multirow{2}{*}{5} & \multirow{2}{*}{ UUS Bank of Yogyakarta } & $38.0 \%$ & $5.0 \%$ & $51.09 \%$ \\
\hline & & $44.5 \%$ & $10.0 \%$ & $50.89 \%$ \\
\hline \multirow{2}{*}{6} & \multirow{2}{*}{ UUS Bank of DKI } & $42.5 \%$ & $5.0 \%$ & $50.67 \%$ \\
\hline & & $50.5 \%$ & $10.0 \%$ & $50.66 \%$ \\
\hline \multirow{2}{*}{7} & \multirow{2}{*}{ UUS Bank of JaTim } & $55.5 \%$ & $5.0 \%$ & $50.32 \%$ \\
\hline & & $64.5 \%$ & $10.0 \%$ & $50.81 \%$ \\
\hline \multirow{2}{*}{8} & \multirow{2}{*}{ UUS Bank of JaTeng } & $53.5 \%$ & $5.0 \%$ & $50.54 \%$ \\
\hline & & $60.8 \%$ & $10.0 \%$ & $50.04 \%$ \\
\hline \multirow{2}{*}{9} & \multirow{2}{*}{ UUS Bank of KalBar } & $29.0 \%$ & $5.0 \%$ & $50.52 \%$ \\
\hline & & $34.5 \%$ & $10.0 \%$ & $50.16 \%$ \\
\hline \multirow{2}{*}{10} & \multirow{2}{*}{ UUS Bank of KalSel } & $38.0 \%$ & $5.0 \%$ & $50.09 \%$ \\
\hline & & $45.0 \%$ & $10.0 \%$ & $51.29 \%$ \\
\hline \multirow{2}{*}{11} & \multirow{2}{*}{ UUS Bank of KalTim } & $39.2 \%$ & $5.0 \%$ & $50.37 \%$ \\
\hline & & $47 \%$ & $10.0 \%$ & $50.33 \%$ \\
\hline \multirow{2}{*}{12} & \multirow{2}{*}{ UUS Bank of SulSelBar } & $41.0 \%$ & $5.0 \%$ & $50.00 \%$ \\
\hline & & $48.0 \%$ & $10.0 \%$ & $50.78 \%$ \\
\hline \multirow{2}{*}{13} & \multirow{2}{*}{ UUS Bank of Jambi } & $40 \%$ & $5.0 \%$ & $50.34 \%$ \\
\hline & & $48 \%$ & $10.0 \%$ & $50.62 \%$ \\
\hline \multirow{2}{*}{14} & UUC Dople of DTN & $39 \%$ & $5.0 \%$ & $50.93 \%$ \\
\hline & UUS Bank of BTN & $46.5 \%$ & $10.0 \%$ & $50.29 \%$ \\
\hline & & $29 \%$ & $5.0 \%$ & $50.29 \%$ \\
\hline 15 & UUS Bank of Permata & $36.5 \%$ & $10.0 \%$ & $50.86 \%$ \\
\hline & & $40 \%$ & $5.0 \%$ & $50.11 \%$ \\
\hline 16 & UUS Bank of CIMB & $47.5 \%$ & $10.0 \%$ & $50.44 \%$ \\
\hline & & $83 \%$ & $5.0 \%$ & $50.95 \%$ \\
\hline 17 & UUS Bank of OCBC & $93 \%$ & $10.0 \%$ & $50.51 \%$ \\
\hline & & $68 \%$ & $5.0 \%$ & $50.44 \%$ \\
\hline 18 & UUS Bank of Danamon & $77.5 \%$ & $10.0 \%$ & $50.55 \%$ \\
\hline & & $32.5 \%$ & $5.0 \%$ & $50.25 \%$ \\
\hline 19 & UUS Maybank Indonesia & $38.05 \%$ & $10.0 \%$ & $50.28 \%$ \\
\hline 20 & UUIC Dopl of Cinorme & $27 \%$ & $5.0 \%$ & $50.51 \%$ \\
\hline 20 & uUs Bank of sinarmas & $34 \%$ & $10.0 \%$ & $50.20 \%$ \\
\hline
\end{tabular}

Sumber: Data diolah

Another study with a sample object of 11 banks consisting of 4 sharia banks resulting from spin-offs, 5 sharia business units, and two sharia commercial banks 
The alternative strategies for accelerating islamic banking growth: mergers, spinoffs, acquisitions and conversions.

found similar results ${ }^{8}$. In addition, these results are similar to studies specializing in regional development banks 9 .

Spin-Off

Spin-off can define as an effort to separate or transfer some of the assets of a company which then becomes an independent company, while the company which conducts the separation or transfer still operates and becomes the holding company of the independent company, which is also called a subsidiary company ${ }^{10}$. Many companies make spinoffs to increase their competitiveness and create value for shareholders by focusing on their core business ${ }^{11}$.

There are two groups that have different views related to spin-offs in the Islamic banking industry. The first group is that which states that the spin-off has a positive impact on the performance of Islamic banks. The spin-off policy has shown differences in performance in the five aspects of financial ratios (CAR, NPF, FDR, ROA, and ROE) in the spin-off banks ${ }^{12}$. There is also shows a differences performance such as asset ${ }^{13}$, profit, and deposit funds between pre and post spinoff ${ }^{14}$. The similar result also shows that there is a differences on ROA between pre and post spin-off ${ }^{15}$.

Next is the second group which states that the spin-off policy does not affect the performance of Islamic banks. Previous research found that there was no

${ }^{8}$ M Nur Rianto Al Arif, Nachrowi Djalal Nahcrowi, Mustafa Edwin Nasution, \& T. M. Zakir Mahmud. (2018). Evaluation of The Spin-offs Criteria: A Lesson from the Indonesian Islamic Banking Industry. Iqtishadia, Vol. 11 (1), 85

9 Ismawati Haribowo. (2017). The Indonesian Islamic Bank's Spin-off: a Study in Regional Development Banks. Al-Iqtishad: Jurnal Ilmu Ekonomi Syariah (Journal of Islamic Economics), Vol. 9(1), 53

${ }^{10}$ Rizqullah. (2013). Pemilihan Metode Spin-Off Unit Usaha Syariah Bank Umum Konvensional Menjadi Bank Umum Syariah di Indonesia. (Unpublished Dissertation). Jakarta: IEF Trisakti

11 J. Beeson, \& C. Hyden. (2002). Corporate Spin-offs: Gaining focus and unleashing stockholder value. Orange County Business Journal, 39, 14.

${ }^{12}$ Amalia Nasuha. (2012). Dampak Kebijakan Spin-Off Terhadap Kinerja Bank Syariah. AlIqtishad: Jurnal Ilmu Ekonomi Syariah (Journal of Islamic Economics), Vol. 4 (2), 241

${ }^{13}$ Sallsa Khairunnisa., \& Miftakhul Khasanah. (2018). Tingkat Efisiensi Perbankan Syariah Pasca Spin-off dengan Metode Two-Stage Data Envelopment Analysis. Al-Tijary, Vol. 4 (1), 11.

${ }^{14}$ A. Taga., K. Nawawi., \& A. Kosim. (2019). Perkembangan Perbankan Syariah Sebelum dan Sesudah Spin-off. Tafaqquh: Jurnal Hukum Ekonomi Syariah dan Ahwal Syahsiyah, Vol. 4(1), 78.

15 Abdul Hamid. (2015). The Impact of Spin-off Policy To The Profitability on Indonesian Islamic Banking Industry. Al-Iqtishad: Jurnal Ilmu Ekonomi Syariah (Journal of Islamic Economics). Vol. 7 (1): 131 
difference in financing growth between before and after the spin-off ${ }^{16}$. The level of efficiency of Islamic banks as a result of spin-offs even decreases after the spinoff ${ }^{17}$. This spin-off policy needs a comprehensive evaluation ${ }^{18}$, especially on Islamic business units owned by regional development banks ${ }^{19}$.

One of the factors that determine the success of a separation process is the size of the parent company ${ }^{20}$. The greater the size of the parent company, the separation process will be more successful than the separation process carried out by companies with smaller sizes. Company size is one of the factors affecting the growth of the separated subsidiary ${ }^{21}$.

The Requirements for the spin-off of Islamic business units into Islamic banks must really go through a rigorous process, including22: First, the capital aspects of the spin-off bank must be adequate, although capital is not the only critical factor that contributes to the bank's improvements ${ }^{23}$. at least the spin-off bank has a core capital of 1 trillion rupiah. Second, the minimum amount of assets of the relevant Islamic business unit. At least the spin-off banks must have assets of at least 20 trillion rupiah. Third, financial performance before the spin-off must be good in the last three to five years. If the parent bank decides to spin off its Islamic business unit, this needs to be well prepared. Preparation is not only related to technical aspects, but also to improving the performance of sharia business units. a company that has good performance before the spin-off will have a greater

${ }^{16}$ Al Arif, M. N. R. (2015). The Effect of Spin-off Policy on Financing Growth in Indonesian Islamic Banking Industry. Jurnal Al-Ulum, Vol. 15 (1), 173

${ }^{17}$ M. Nur Rianto Al Arif. (2015). Keterkaitan Kebijakan Pemisahan Terhadap Tingkat Efisiensi Pada Industri Perbankan Syariah di Indonesia. Jurnal Keuangan dan Perbankan, Vol. 19 (2), 295.

${ }^{18}$ M Nur Rianto Al Arif, Nachrowi Djalal Nahcrowi, Mustafa Edwin Nasution, \& T. M. Zakir Mahmud. (2017). The Islamic Banking Spin-Off: Lessons from Indonesian Islamic Banking Experiences. Journal of King Abdul Aziz University: Journal of Islamic Economics, Vol. 30 (2), 117

${ }_{19}$ Ismawati Haribowo. (2017). The Indonesian Islamic Bank's Spin-off: a Study in Regional Development Banks. Al-Iqtishad: Jurnal Ilmu Ekonomi Syariah (Journal of Islamic Economics), Vol. 9(1), 53

${ }^{20}$ George Alfred Johnson, Robert M Brown, \& Dana J Johnson. (1994). The Market Reaction to Voluntary Corporate Spinoffs: Revisited. Quarterly Journal of Business and Economics, Vol. 33(4), 44

21 Lindhom-Dahlstrand. (2000). Entrepreneurial Origin adn Spin-off Performance. Paper presented at the $20^{\text {th }}$ Annual Entrepreneurship Research Conference, Babson College, USA

${ }^{22}$ M Nur Rianto Al Arif, Nachrowi Djalal Nahcrowi, Mustafa Edwin Nasution, \& T. M. Zakir Mahmud. (2018). Evaluation of The Spin-offs Criteria: A Lesson from the Indonesian Islamic Banking Industry. Iqtishadia, Vol. 11 (1), 90

${ }^{23}$ Muhammad Budi Prasetyo, Rizky Luxianto, Rahmat Aryo Baskoro, Wardatul Adawiyah, \& Niken Iwani S Putri. (2019). The Role of Capital on Islamic Bank Spin-Offs in Indonesia. The South East Asian Journal of Management, Vol. 13 (2), 119 
The alternative strategies for accelerating islamic banking growth: mergers, spinoffs, acquisitions and conversions.

tendency to have better performance after the spin-off ${ }^{24}$. Fourth, the commitment of the parent bank to the development of the Islamic banking industry.

\section{Merger and Acquisition}

Merger can be interpreted as a business union, so mutual ownership is achieved. Mergers can be horizontal mergers and vertical mergers. The merger strategy between sharia business units can be included in the horizontal merger category. Islamic financial institutions (including Islamic banks) will get a benefit from consolidation in several ways ${ }^{25}$. First, the Islamic financial institution can expand the scope of their products and services. Second, the Islamic financial institution can build a solid infrastructure for new services on both sides. Third, Islamic financial institutions can get an efficiency gains through diversification and enhance management quality. The merger and acquisition will have a significant difference in post-long-run performance to the control the $\operatorname{crises}^{26}$.

The merger of several Islamic business units will be able to strengthen the capital of the merged sharia bank ${ }^{27}$. In addition, a merger between Islamic business units will make them more ready to compete in the ASEAN economic community ${ }^{28}$.

But, some of the studies found a different result. Merger and acquition doesn't give a positive improvemen in the financial performance ${ }^{29}$ such as return on equity, return on assets, net profit ratio, yield on advance, and yield on

24 Sally Klepper \& Peter Thompson. (2010). Disaggrements and Intra-Industry Spinoffs. International Journal of Industrial Organization, vol. 28(5), 526.

${ }^{25}$ Zamiq Iqbal. (2008). The Impact of Consolidation on Islamic Financial Service Industry. Islamic Economic Studies, 15(2), 79.

${ }^{26}$ Tarek Kandil, \& Dababrata Chowdhury. (2014). Islamic Banks Mergers and Acquisitions Impacts on Performance and Financial Crisis in the United Kingdom. The Developing Role of Islamic Banking and Finance: From Local to Global Perspective (Contemporary Studies in Economic and Financial Analysis, Vol. 95), 120

${ }^{27}$ Kindy Miftah, \& Hendro Wibowo. (2017). Merger and Industrial Acceleration: Study at Indonesian Islamic Banking Industry. Signifikan: Jurnal Ilmu Ekonomi, Vol. 6(1), 29

${ }^{28}$ Khulifa Ahdizia, Dian Masyita, \& Sutisna. (2018). Business Valuation of Islamic Banks in the Merger Plan to Become Indonesia's State-Owned Bank. Etikonomi, Vol. 17(2), 223

${ }^{29}$ Qamar Abbas, Ahmed Imran Hunjra, Rauf I Azam, Muhammad Shahzad Ijaz, \& Maliha Zahid. (2014). Financial Performance of Banks in Pakistan After Merger and Acquisition. Journal of Global Entrepreneurship Research, Vol 4(13), 1 
investment ${ }^{30}$. Merger activity did not have an impact on bank profitability or growth ${ }^{31}$. Merger also had no impact on the rate of return on shareholders' equity and return on assets ${ }^{32}$.

There are several things to consider before deciding on a merger. First, differences in characteristics between Islamic business units to be merged. Second, difficulties in determining the majority shareholder. Third, if there is a liquidity problem then who will be responsible for adding liquidity. Fourth, mergers can have an impact on reducing the number of employees.

\section{Conversion}

Bank Aceh in 2016 officially made a full conversion to Islamic commercial banks. This strategy is the first time carried out by conventional banks in Indonesia. Aceh's bank conversion has a significant impact with the increasing market share of Islamic banks in Indonesia, the target market share of 5\% was finally reached in 2016. The decision to convert Bank of Aceh into a full-fledged Islamic bank was made on May 25, 2015 at a general meeting of shareholders (RUPS). At the beginning of the conversion of Aceh's banks into full-fledged Islamic banks, it was feared that there would be a decline in financial performance. However, this concern is not proven, even the financial performance from Bank of Aceh' after becoming a Islamic bank has increased. The average growth in the total assets of the Bank of Aceh is $8 \%$ per year, the total fund raising is $10 \%$, and the distribution of funding is $5 \%$.

Whereas, the conversion decision at Bank of NTB was made on 31 October 2016 at a general meeting of shareholders. This decision was then followed up with the formation of the Conversion Project Management Team and the Conversion Steering Team (SC) of PT Bank of NTB to become PT Bank of NTB

\footnotetext{
${ }^{30}$ Ritesh Patel. (2018). Pre \& Post Merger Financial Performance: An Indian Perspective. Journal of Central Banking Theory and Practice, Vol. 3, 181.

31 Peter S. Rose. (1987). The Impact of Mergers in Banking: Evidence from a Nationwide Sample of Federally Chartered Banks. Journal of Economics and Business, Vol. 39(4), 289.

32 Hiyam Sujud., \& Boutheina Hachem. (2018). Effect of Mergers and Acquisition on Performance of Lebanese Banks. International Research Journal of Finance and Economics, Vol. 166, 69.
} 
The alternative strategies for accelerating islamic banking growth: mergers, spinoffs, acquisitions and conversions.

Syariah. The formation of this team was carried out to accelerate the next few stages.

There are several considerations in the decision to convert to Islamic banks. First, the majority of the population in the region is Muslim. Second, the application of Islamic law in the province of Aceh. Third, the appeal of the Islamic banking industry which forms the basis of rational choices for conversion ${ }^{33}$.

Some previous studies show the positive impact of the conversion policy that has been carried out both by Bank Aceh and Bank NTB. The changes in Bank of Aceh have received positive reactions from customers ${ }^{34}$. The change to a Fullfledged Islamic bank has an impact on increasing people's interest in saving 35. There is also a significant differences in carrying out the intermediary functions both in terms of the amount of funding and the number of deposits ${ }^{36}$. Conversions made by Bank of Aceh show changes in the level of risk, where the level of risk after conversion is lower than the condition before the conversion is done ${ }^{37}$.

There are several legal consequences of the conversion of conventional banks into Islamic banks. First, changes in business activities. Second, changes in organizational structure. Third, changes in bank supervision. Fourth, changes in the profit distribution process ${ }^{38}$.

There are several factors that must be considered by conventional banks that want to convert to Islamic banks. First, the level of acceptance of customers and stakeholders on the change of status to become Islamic banks. Second, brand equity that you want to develop after conversion. Third, the potential and market

${ }^{33}$ Aji Damanuri. (2012). Rasionalitas Konversi Bank Konvensional ke Bank Syariah. Justicia Islamica, Vol. 9(1), 88

${ }^{34}$ Talbani Farlian., \& Nuraidar. (2017). Meretas Reaksi Jalan Panjang Bank Aceh Konversi Syariah. Jurnal Perspektif Ekonomi Darussalam, Vol. 3(1), 39

${ }^{35}$ Asra Idriyanssyah Purba. (2017). Pengaruh Perubahan Bank Umum Syariah Terhadap Minat Menabung di Bank Aceh Syariah Pada Masyarakat Kabupaten Aceh Tenggara. Human Falah, Vol. 4(1), 72

36 Purwanto. (2018). Fungsi Intermediary Bank Aceh Setelah Melakukan Konversi Menjadi Bank Umum Syariah. Journal of Islamic Economics, Finance, and Banking, Vol. 1 (1 \& 2), 137.

37 Sinarthrya Al Kautsar, Lusiana Indra, Taufan Prasojo Wicaksono, \& Dewi Hanggraeni. (2019). Pengaruh Konversi Bank Konvensional Menjadi Bank Syariah Terhadap Risiko Kebangkrutan Studi Kasus Pada Bank Aceh. E-Jurnal Ekonomi dan Bisnis Universitas Udayana, Vol. 8(6), 550.

${ }^{38}$ Wati Rahmi Ria. (2004). Konversi Bank Umum Konvensional Menjadi Bank Umum Syariah Berdasarkan UU No. 10 Tahun 1998. Hukum dan Pembangunan, Vol. XXXIV (3), 277 
niche that you want to achieve after conversion. Fourth, shareholder alignments with bank developments after conversion...

\section{E. Conclusion}

The results showed that there was not a single sharia business unit that was able to achieve a $50 \%$ share of assets from its parent bank. This shows that the spin-off criteria as contained in the law need to be evaluated. The policy for spinoffs must be carried out carefully. The Spin-offs policy can only be made to Islamic business units that have a minimum value of certain assets (for example 20 trillion) and Islamic business units that have performed well in the past few years. The policy to fully convert into an Islamic bank which has been carried out by two regional development banks namely the Aceh Bank and the NTB Bank was able to show encouraging results. This can be seen from the achievement of a $5 \%$ market share after Bank Aceh made a full conversion to an Islamic bank.

Another alternative strategy that can be taken by Islamic banks is to merge between Islamic business units. This will be able to increase the capital capacity of the sharia business unit. However, this merger needs to be done carefully considering the different characteristics between banks. The last alternative strategy offered is the acquisition of sharia business units by sharia banks that have entered BUKU 2 or BUKU 3. So, the parent bank can focus on its core business.

\section{References}

Abbas, Q., Hunjra, A. I., Azam, R. I., Ijaz, M. S., \& Zahid, M. (2014). Financial Performance of Banks in Pakistan After Merger and Acquisition. Journal of Global Entrepreneurship Research, Vol 4(13), 1-15.

Ahdizia, K., Masyita, D., \& Sutisna. (2018). Business Valuation of Islamic Banks in the Merger Plan to Become Indonesia's State-Owned Bank. Etikonomi, Vol. $17(2), 223-236$.

Al Arif, M. N. R. (2015). Keterkaitan Kebijakan Pemisahan Terhadap Tingkat Efisiensi Pada Industri Perbankan Syariah di Indonesia. Jurnal Keuangan dan Perbankan, Vol. 19 (2), 295-304

Al Arif, M. N. R. (2015). The Effect of Spin-off Policy on Financing Growth in Indonesian Islamic Banking Industry. Jurnal Al-Ulum, Vol. 15 (1), 173-184. 
The alternative strategies for accelerating islamic banking growth: mergers, spinoffs, acquisitions and conversions.

Al Arif, M. N. R., Nahcrowi, N. D., Nasution, M. E., \& Mahmud, T. M. Z. (2017). The Islamic Banking Spin-Off: Lessons from Indonesian Islamic Banking Experiences. Journal of King Abdul Aziz University: Journal of Islamic Economics, Vol. 30 (2), 117-133.

Al Arif, M. N. R., Nahcrowi, N. D., Nasution, M. E., \& Mahmud, T. M. Z. (2018). Evaluation of The Spin-offs Criteria: A Lesson from the Indonesian Islamic Banking Industry. Iqtishadia, Vol. 11 (1), 85-104.

Al Kautsar, S., Indra, L., Wicaksono, T. P., \& Hanggraeni, D. (2019). Pengaruh Konversi Bank Konvensional Menjadi Bank Syariah Terhadap Risiko Kebangkrutan Studi Kasus Pada Bank Aceh. E-Jurnal Ekonomi dan Bisnis Universitas Udayana, 8(6), 550-566.

Beeson, J., \& Hyden, C. (2002). Corporate Spin-offs: Gaining focus and unleashing stockholder value. Orange County Business Journal, 39, 14-25

Damanuri, A. (2012). Rasionalitas Konversi Bank Konvensional ke Bank Syariah. Justicia Islamica, Vol. 9(1), 69-96.

Farlian, T., \& Nuraidar. (2017). Meretas Reaksi Jalan Panjang Bank Aceh Konversi Syariah. Jurnal Perspektif Ekonomi Darussalam, Vol. 3(1), 39-50.

Hamid, A. (2015). The Impact of Spin-off Policy To The Profitability on Indonesian Islamic Banking Industry. Al-Iqtishad: Jurnal Ilmu Ekonomi Syariah (Journal of Islamic Economics), Vol. 7 (1), 131-140.

Haribowo, I. (2017). The Indonesian Islamic Bank's Spin-off: a Study in Regional Development Banks. Al-Iqtishad: Jurnal Ilmu Ekonomi Syariah Uournal of Islamic Economics), Vol. 9(1), 53-68.

Iqbal, Z. (2008). The Impact of Consolidation on Islamic Financial Services Industry. Islamic Economic Studies, Vol. 15(2), 79-103.

Johnson, G. A., Brown, R. M., \& Johnson, D. J. (1994). The Market Reaction to Voluntary Corporate Spinoffs: Revisited. Quarterly Journal of Business and Economics, Vol. 33(4), 44-59

Kandil, T., \& Chowdhury, D. (2014). Islamic Banks Mergers and Acquisitions Impacts on Performance and Financial Crisis in the United Kingdom. The Developing Role of Islamic Banking and Finance: From Local to Global Perspective (Contemporary Studies in Economic and Financial Analysis, Vol. 95), 119-140. https://doi.org/10.1108/S1569-3759(2014)0000095016.

Khairunnisa, S., \& Khasanah, M. (2018) Tingkat Efisiensi Perbankan Syariah Pasca Spin-off dengan Metode Two-Stage Data Envelopment Analysis. Al-Tijary, Vol. 4(1), 11-24.

Klepper, S., \& Thompson, P. (2010). Disaggrements and Intra-Industry Spinoffs. International Journal of Industrial Organization, vol. 28(5), 526-538

Lindhom-Dahlstrand, A. (2000). Entrepreneurial Origin adn Spin-off Performance. Paper presented at the 20 $0^{\text {th }}$ Annual Entrepreneurship Research Conference, Babson College, USA 
Miftah, K., \& Wibowo, H. (2017). Merger and Industrial Acceleration: Study at Indonesian Islamic Banking Industry. Signifikan: Jurnal Ilmu Ekonomi, Vol. 6(1), 29-48.

Nasuha, A. (2012). Dampak Kebijakan Spin-Off Terhadap Kinerja Bank Syariah. AlIqtishad: Jurnal Ilmu Ekonomi Syariah (Journal of Islamic Economics), Vol. 4 (2), 241-257.

Pambuko, Z. B. (2019). Kebijakan Spin-off dan Efisiensi Perbankan Syariah di Indonesia. Ihtifaz: Journal of Islamic Economics, Finance, and Banking, Vol. 2(1), 21-38.

Patel, R. (2018). Pre \& Post Merger Financial Performance: An Indian Perspective. Journal of Central Banking Theory and Practice, Vol. 3, 181-200.

Prasetyo, M. B., Luxianto, R., Baskoro, R. A., Adawiyah, W., \& Putri, N. I. S. (2019). The Role of Capital on Islamic Bank Spin-Offs in Indonesia. The South East Asian Journal of Management, Vol. 13 (2), 119-139.

Purba, A. I. (2017). Pengaruh Perubahan Bank Umum Syariah Terhadap Minat Menabung di Bank Aceh Syariah Pada Masyarakat Kabupaten Aceh Tenggara. Human Falah, Vol. 4(1), 72-86.

Purwanto. (2018). Fungsi Intermediary Bank Aceh Setelah Melakukan Konversi Menjadi Bank Umum Syariah. Journal of Islamic Economics, Finance, and Banking, Vol. 1 (1 \& 2), 137-145.

Ria, W. R. (2004). Konversi Bank Umum Konvensional Menjadi Bank Umum Syariah Berdasarkan UU No. 10 Tahun 1998. Hukum dan Pembangunan, Vol. XXXIV (3), 268-278.

Rizqullah. (2013). Pemilihan Metode Spin-Off Unit Usaha Syariah Bank Umum Konvensional Menjadi Bank Umum Syariah di Indonesia. (Unpublished Dissertation). Jakarta: IEF Trisakti

Rose, P. S. (1987). The Impact of Mergers in Banking: Evidence from a Nationwide Sample of Federally Chartered Banks. Journal of Economics and Business, Vol. 39(4), 289-312. https://doi.org/10.1016/0148-6195(87)90024-5.

Sujud, H., \& Hachem, B. (2018). Effect of Mergers and Acquisition on Performance of Lebanese Banks. International Research Journal of Finance and Economics, Vol. 166, 69-77.

Taga, A., Nawawi, K., \& Kosim, A. (2019). Perkembangan Perbankan Syariah Sebelum dan Sesudah Spin-Off. Tafaqquh: Jurnal Hukum Ekonomi Syariah dan Ahwal Syahsiyah, Vol. 4(1), 78-110. 